\title{
A Case Study on the Prospects of Customer- Brand Relationship in Tourism
}

\author{
Sneha $N^{*}$
}

\begin{abstract}
The travel and tourism industry is struggling to gain markets' share and sustain profitability in today's fiercely competitive and economically demanding environment. The industry should develop new ways to manage their customer relationship to optimize customer loyalty and revenues. Customer retention is an integral aspect of sales planning. It is a known fact in the marketing circles that it costs companies three to four times more to find new customers than to retain existing ones. This research paper deals with a case study of the prospects of customer brand relationship scenario of some popular tour operators in Bangalore analysed with the help of qualitative interviews, Literature findings and through a constructive approach to understand Customer Brand Relationship in tourism.
\end{abstract}

Keywords: Brand, Customer Relationship Management

\section{Introduction}

Modern customer relationship management strategy is all about capturing customer's heart share more than his mind share by offering a differentiating value proposition through various innovative ideas (Thryambakam \& Bethapudi, 2013). An unsatisfied customer's experience will translate into negative

* Lecturer, Department of Travel \&Tourism, Mount Carmel College (Autonomous) Bangalore, India; sneha2188@gmail.com 
publicity. Hence, end user satisfaction is an important task for all the stake holders involved in tourism and hospitality industry.

The most talked about brands are those that create a special connection with their customers and promote brand advocacy. The best advocacy programs enable customers to hold the image of a brand in their own hands. They empower company's fans, turning a one-way marketing channel into multiple promotional conversations (Walter 2013).

Few years ago, customer relationship management (CRM) was not feasible for small tourism businesses. The CRM industry was dominated by large companies like Thomas Cook, SOTC, Cox \& Kings and the like - that primarily worked with other large companies to develop high-end CRM applications. Today it is available for even the smallest business. There are also competing Web-based sales-management tools that offer collaboration, leadcapturing, and management tools (All Business, n.d.).

A well-implemented CRM strategy will pay off immediately and improve productivity throughout the organization (All Business, n.d.). Effective customer and brand relationship together is the way forward. Those organizations which neglect to adopt the CRM practices and brand management will face a negative impact on their turnover. Thus, customer relations are beginning to be a strong feature for both the big and small players in the tourism industry.

\section{Prospects of CRM in Tourism Industry}

In the era of network marketing, tourism enterprises by means of a variety of information technology are facilitating a sound customer relationship management since it is the need of the hour. The concept of customer relationship management is used in tourism businesses help solve the process of segmentation, service quality, problems of instability, thus bringing overall better services to the tourists. As a result CRM in general lays a good foundation for the sustainable development of tourism.

Customers have more choices than ever before, and a vendor's arch competitor is often just a mouse-click away. Without customers, products don't sell and revenues don't materialize 
(Traderslibrary.com, 2014). Thus, Relationship marketing is emerging as the core marketing activity for businesses operating in fiercely competitive environments. On average, businesses spend six times more to acquire customers than they do to keep them (Gruen, 1997). Therefore, many firms are now paying more attention to their relationships with existing customers to retain them and increase their share of customer's purchases (Shainesh \& Mohan, n.d.).

Worldwide service organizations have been pioneers in developing customer retention strategies (Shainesh \& Mohan, n.d.). Some of the core strategies of CRM include developing a core service around which to build a sound customer relationship, customizing the relationship to each individual customer, augmenting the core service of the company with extra benefits, better pricing to encourage customer loyalty and marketing to employees so that they will in turn perform well for customers (Berry 1983)

According to A.N Sarkar, "Developments in information technology, data warehousing and data mining have made it possible for firms to maintain a one to one relationship with their customers. Firms can now manage every single contact with the customer from account management personnel, call centres, interactive voice response systems, on-line dial-up applications, and websites to build lasting relationships. These interactions can be used to glean information and insights about customer needs and their buying behaviour to design and develop services, which help create value for the customers as well as the firms. Although customised as well as off the shelf technological solutions are available in the marketplace, businesses need to do a lot more than just adopt these solutions to implement customer relationship management (CRM) practices".

It is important to understand the three crucial phases in which CRM support the relationship between a business and its customers: Acquire: CRM can help a business acquire new customers through contact management, selling, and fulfillment. Enhance: web-enabled CRM combined with customer service tools offers customers service from a team of sales and service specialists, which offers customers the convenience of one-stop shopping. Retain: CRM software and databases enable a business to identify 
and reward its loyal customers and further develop its targeted marketing and relationship marketing initiative (Xincrm.com, 2014).

\section{Prospects of CRM and Brand Perception in India}

Tourism industry, especially the local tourism industry which usually cannot afford expensive marketing and CRM programs, may have a centralized approach by a national committee. Competition concerning the most valuable travellers will increase and hence the need for adequate destination marketing is of paramount importance.

Implementing CRM on a national and regional basis is a matter of the economic policy and will support the local economy regarding employment and national/ local contribution and monetary impact to the GDP. In addition, CRM is fundamental in the development of a destination's image or brand, which is important for differentiating the destination from others and key to consumer decisions on choosing their tourist destination. By establishing a CRM tool one can support the building of a brand and generate additional values for both travellers and the stakeholders in the local tourism industry. CRM is a lot more than technology, keeping in mind that IT supports tourism industry with dedicated consulting services (ITO, n.d.).

Customer-centric marketing in India emphasizes understanding and satisfying the needs, wants, and resources of individual consumers and customers rather than those of mass markets or market segments. In customer-centric marketing, marketers assess each customer individually to determine whether to serve that customer directly or via a third party. Also, customer-centric marketers determine whether to create an offering that customizes the product and/or some other elements of the marketing mix or standardize the offering.

Managers must continually monitor how consumers perceive the brand both in large and small travel agencies. It is very important that brand marketers appreciate the role of perceptual processes when developing brand communication strategies. Consumers perceive brands in very personal ways and attach their own values to them. The services are value engineered to satisfy a specific 70 
target's minimum purchase conditions such as pricing, availability etc and as repeat buying occur; the brand would evolve through better matching of resources to meet customer needs.

The substantial increases in the volume of tourist information available as a consequence of rapid technological change, globalisation and the blurring boundaries of competition are the main reasons that there is a paradigm shift occurring in the tourism industry the world over. The modern customers are more educated, experienced, independent and demanding. Information technology is opening up an astonishing array of travel and vacation options for this new type of tourist. To remain competitive in today's global economy, tourism destinations and industry players alike must adapt.

There is an urgent need to strengthen customer relations for ways to extend market reach, improve quality and customer service so as to increase profitability. In general the main challenge is to track potential travellers, to stimulate and reward them for (ITO, n.d.).

\section{CRM and Brand Perception in Bangalore}

It is essential to determine the approach being adopted by tourism industry for relationship marketing in Bangalore. Bangaloreans are brand conscious when it comes to clothes, electronics etc. Hence, it is necessary to find out if it holds good even in the selection of tour operators as well. The research paper is focused on the following major issues:

Do managers in service firms believe that their processes are customer centric?

Do they select technology based on an understanding of customer needs?

Have they empowered their employees to deliver superior service?

Do they have a customer knowledge strategy?

How well do they manage their customer relationships and brands?

For small businesses, basic client service can be accomplished by a contact manager system: an integrated solution that lets 
organizations and individuals efficiently track and record interactions, including emails, documents, jobs, faxes, scheduling, and more. These tools usually focus on accounts rather than on individual contacts. They also generally include opportunity insight for tracking sales pipelines plus added functionality for marketing and service. As with larger enterprises, small businesses are finding value in online solutions, especially for tourism businesses.

Small businesses often believe the benefits of CRM are beyond their reach. Although these companies have a lower turnover and a smaller workforce than large enterprises, they often have the same business processes, some times the same disparate back-office systems and even the same complexity as large companies. As a result, they face the same challenge: to create a single view of the customer across the organization, so that they can offer consistent and profitable service to the customers.

Business growth brings the small enterprises to the realization that it can no longer sustain the informal, regular personal interaction with its customers. Often a differentiator factor is crucial to compete successfully with larger rivals. Close customer understanding allows tour operators to tailor their offerings in response to customer needs and new competitors. Under these circumstances, a CRM system can be a strategic tool for retaining customers and acquiring new ones as this helps in the growth of tourism business exponentially. CRM applications aimed specifically at tourism industry often fail to measure up to the organization's complexity. The lack of close integration with the rest of the business' IT infrastructure can rob the tour operators of CRM's full potential. The lack of customization and configuration options can make the applications inflexible.

At this stage the small business owner needs to consider the most effective way for a CRM system to be incorporated into its IT infrastructure. CRM is best thought of as a strategy - not a technology - and correctly implemented it can significantly reduce errors and costs of sale in addition to increasing sales revenue and thereby increase the brand perception. An effective CRM strategy involves, in the main, the closer integration of existing systems. Valuable customer information 72 
already resides within existing information systems and the creation of a completely new application that requires a complete new set of information is a duplication of effort, which resourcestrapped tour operators can do without.

\section{Need for the Study}

Much work has not been done in this area of tourism in a coherent and comprehensive manner; therefore there is a need for a study of this kind. No study on tourism can be regarded as complete without a thorough research on Customer Relationship Management, as any day Customer is the King. Hence, it becomes all the more essential to find out the relationship between CRM and Brand perception in the tourism industry. The study will be relevant for the tourism industry which can improve CRM initiatives to increase brand perception of customers not only in Bangalore but also in India in general.

\section{Operational Definition}

A case study of the "Prospects of Customer Brand Relationship of Tour Operators in Bangalore, refers to the customers of tour operators in Bangalore which is used for this research.

\section{Customer Relationship Management}

CRM is the practice of analyzing and utilizing marketing databases and leveraging communication technologies to determine corporate practices and methods that will maximize the lifetime value of each individual customer to the firm.

\section{Brand Perception}

Brand perception is about how the customers perceive a particular brand. People interpret messages and images through their own perceptions. It is the buyer who forms a mental vision of the brand.

\section{Variables of the Study}

Dependent variable: Brand perception is the dependent variable. Dependent Variable (DV) is the presumed effect.

Independent variable: Independent variable (IV) is CRM. IV is the variable that is varied or manipulated by the researcher, and 
the dependent variable is the response that is measured. An independent variable is the presumed cause.

Background variables: It also consists of Background variables such as Age, Gender, Marital status, Occupation, etc. Background variables are biographical data of an individual which is also called the performa.

\section{Scope of the Study}

The case study is limited to tour operators in Bangalore. The study will help to determine if there is a reciprocal relationship between Customer Relationship Management and Brand Perception i.e. whether better brand perception depends upon CRM or vice versa and whether revenue generation in a firm depends upon better CRM or Brand Perception which determines its future prospects.

\section{Objectives of the Study}

To study the prospects of Customer Brand Relationship of Popular Tour Operators in Bangalore

To study the existing mechanism of CRM in the tourism industry of popular tour operators in Bangalore.

To identify innovative ideas used by the tourism industry to gain customer loyalty and attract new clientele.

\section{Hypothesis}

Brand Perception is dependent upon Customer Relationship Management.

\section{Sample and Methodology}

Sample: Tour Operators in Bangalore

Sample size: Three tour operators and twenty customers each 


\section{Methodology}

Primary data: The data has been collected through qualitative interviews with small and large tour operators. Observations were made in these companies in a constructive approach to understand $\mathrm{CRM}$ and quantitative data on brand perception collected from their clientele database.

Secondary data: Literature findings gathered in order to collect the secondary data

\section{Reliability and Validity}

The questionnaires were constructed according to the variables of the study. It was followed by a pilot study. Questionnaires were given to 40 random customers of tour operators in Bangalore. For this two sets of questionnaires were prepared on the two variables - Customer Relationship Management (CRM) and Brand perception. This data was then used for item analysis. Item analysis was done by coding all the items in the questionnaire. The item analysis data was used to conduct the reliability analysis which was done to find out the accuracy level of the questionnaires.

Table 1: Reliability values for the questionnaires

\begin{tabular}{|l|c|}
\hline \multicolumn{1}{|c|}{ Summary } & Values \\
\hline CRM alpha score indicates $83.3 \%$ accuracy & .833 \\
\hline $\begin{array}{l}\text { Brand perception alpha score indicates } 83 \% \\
\text { accuracy }\end{array}$ & .830 \\
\hline
\end{tabular}

\section{Statistical analysis}

The reliability analysis created a standardized tool to conduct the study and proceed with the data collection from the sample size. The data collected from the sample were fed into SPSS which is statistical analysis software in order to thoroughly analyze the results.

\section{Limitations}

Since both quantitative and qualitative methods were used, the possibility of performing a large number of interviews and 
observations was limited. The results would not be representative for all travel large and small tour operators in Bangalore but only for the group of companies that will be interviewed, especially when considering the geographical size of Bangalore. An anticipated risk with the method is the organizations and persons to be interviewed may not co-operate and also genuinity of their responses cannot be relied upon completely.

\section{Popular Organizations selected for the Survey}

\section{MakeMyTrip}

MakeMyTrip went on to pioneer the entire online travel industry in India. It has revolutionized the travel industry over the years. It was founded in the year 2000 by Deep Kalra. It was created to empower the Indian traveller with instant booking and comprehensive choices, the company began its journey in the USIndia travel market. It aimed to offer a range of best-value products and services along with cutting-edge technology and dedicated round-the-clock customer support.

According to the information in their official website, "After consolidating its position in the market as a brand recognized for its reliability and transparency, MakeMyTrip followed its success in the US by launching its India operations in 2005. With the foresight to seize the opportunities in the domestic travel market, brought on by a slew of new airlines, it offered travellers the convenience of online travel bookings at rock-bottom prices. Rapidly, it became the preferred choice of millions of travellers who were delighted to be empowered by a few mouse clicks. “

\section{CRM Mechanism in MakeMyTrip}

When a customer drops in to MakeMyTrip his/her entire contact details are stored in a database called CRM (Customer Relationship Management). This software helps the organization in recording customer queries and helping the executives to provide a suitable tour package as per the taste and preferences.

Once any customer makes an enquiry at MakeMyTrip their contact details is stored with them for ever. While providing the details the executive feeds the details through the CRM tool in which there 76 
are three important stages in the query call back, solved and closed. Call Back means the executive would call the client after sending the details of a package. Solved would mean that the executive has successfully managed to solve the queries of the client and closed stage is where client confirms the package and finishes the booking procedure.

Once the client wants to book the package, a booking ID through CRM is created at MakeMyTrip. This booking ID would be sent to the client by an SMS. To the same ID all the contact details and package details are stored. Even the payment done by the concerned customer is collected and stored in this system. Any further information about any customer or booking can be retrieved through the same CRM tool.

After booking, the client would keep in touch with the operation team by handing over all the documents and all the changes would be taken care by them. After the tour, they also take feed back from the client to improve their products and services.

It is their philosophy that customers' expectations is what any organization should map and strive to meet and not rely on current internal processes alone to determine resolution of any instance. The Customer Delight Manager (CDM) helps to give their customers an experience of delight. Even though they have a 24 hour post sales customer care center, for cases where-in customers feel that they have not received fair/ expected resolution and is still not fully satisfied then the case is addressed by the Customer Delight Manager. The manager's mandate is to resolve the grievance within 24 hours.

The CDM takes pro-active steps to ensure customer delight. They check third-party blogs to seek dissatisfied customers and resolve their issues, and also call customers to take first hand feedback on service and product from MakeMyTrip. Voice of Customer survey is conducted every day to find out if the issue in question has been resolved and closed. The survey includes mandatory questions like:

How many times did you have to call?

Were you satisfied with agent interaction?

Did agent resolve your problem on that call? 
Are you satisfied with MMT?

The survey responses are reviewed weekly and necessary changes are made in the system. Differentiating factors of the practice from its competitors is about driving internal focus towards offering First Contact Resolution (FCR) as the information captured through Voice of Customer Survey is fed back to the Customer Service team. The Customer Service team thereon uses these scores to raise internal Benchmarks on FCR.

Over the years, MakeMyTrip.com has launched an entire customer relationship management initiative under the brand name Super Tripper. MakeMyTrip has an efficient CRM platform known as the CRM Connect which contains the database of all customers of MakeMyTrip and keeps a track of all transactions with each customer which is designed end to end. They also have other programmes which were launched for customers. The first programme entitles any customer who has bought a travel package from MakeMyTrip worth Rs. 10,000 and above to a one-year subscription of Outlook Traveller free. The Outlook people will be sending the subscription. Makemytrip.com has tied up with Outlook Traveller for this promotion. This continued for quite some time.

Another programme was called High5. Under this scheme the customers could refer their friends to buy MakeMyTrip vouchers. If the friends buy the voucher, then the person who has recommended them gets an e-voucher worth Rs. 500, which he can redeem in his next buy. This scheme was started and MakeMyTrip kept introducing new schemes in the High5 programme.

The main purpose for launching these schemes was the benefits it brought to MakeMyTrip. Their own customers will be acting as brand ambassadors and they will promote MakeMyTrip through this initiative. The advantage will be that it will help them lower their marketing spends in the long run.

Likewise, an exclusive and free travel application for Blackberry Smart phones, 'MakeMyTrip Mobile' was launched in partnership with DbyDx Software. This was designed to ensure easy travel planning with added security, the application has already witnessed thousands of downloads with great reviews from 78 
various forums. Applications that provide location based services include a vehicle tracking system and location based targeted mobile advertising, while those serving enterprise purpose include Mobile CRM, Client for Salesforce and other CRM tools.

MMT believes in the strength of brand power. Quality of services, user-friendly website experience, focus on customers and efficacy of marketing programs have enabled them to capture a significant share of the domestic air tickets market in India. They have a monopoly in the tourism markets both domestic and outbound sectors due to their strong CRM systems in place.

\section{Thomas Cook}

In 1841, young Thomas Cook arranged an 11-mile train journey for a motley group of passengers from Leicester to Loughborough. And it marked the beginning of a chapter in history. He went on to introduce a railway tour of Europe. But it wasn't until the early 1860s that he began the travel firm, Thomas Cook and Son, which included tours of the USA. The Company also started operations for military transport and postal services for England and Egypt during the 1880s. The world got around and by the early 1900s, the who's who of the era - kings, politicians, bishops and professors patronised Thomas Cook's travel itinerary. In 1881, Thomas Cook started its India operations, with its first office being set up in Kolkata.

\section{CRM Mechanism in Thomas Cook}

Thomas Cook has a practice that is called PRIDE. Every Letter in the word PRIDE has its own meaning which in every essence reflects the standards they aim to maintain constantly which makes them a global brand.

P stands for pioneering our future,

$\mathrm{R}$ stands for respecting the individuals and united as one team, I stands for integrity,

D stands for delighting the customer and

E stands for excellence

Additionally, there are set of protocols which every employee of Thomas Cook follows, giving a meaning to the PRIDE. Apart from these, normal customer feedback form is given to customers to 
know their opinion about the products and services of Thomas Cook. The $24 \mathrm{hrs}$ Call centre is equipped to solve certain customer queries automatically. Tele calls are an important way connecting with the clientele database. This helps to provide periodic update of new products and services of Thomas Cook.

Follow ups is another important technique to ensure that potential customers are converted into actual customers. Gifts, discounts, customer loyalty programs, cash back offer and many more benefits are offered by Thomas Cook to enhance their customer relations and improve customer retention.

Another special practice unique to Thomas Cook is ECHO. ECHO stands for Every Customer Has Opportunity, Thomas Cook's internal customer database software, where all the front liners or the customer facing staff need to update the details of each client (possibly) visiting their office premises and enquiring on products and services. Example: Customer name, their phone no., email id, addresses if possible, enquiry details, status etc. This is a very new initiative in Thomas Cook which started about a year and half back.

This database helps in getting an extra edge in reaching the clients through mail or tele calls during promotions/offers or updation of any new product launch. It basically makes the work easy in reaching their old customers. During various Road Shows this database helps them a lot in attracting and reconnecting with their old clients to create repeat purchase.

Thomas Cook believes that the key to customer satisfaction is by building a healthy relationship with every customer walk-ins in any branch of Thomas Cook. It is how well they interact with the clients and how well they understand the needs and requirements of the customer and offer the products and services accordingly. These practices are the pillars of strength behind Thomas Cook's success story.

\section{Club 7 Holidays}

Club 7 Holidays are a subsidiary of the Future Group. The Head Office is located in Kolkata. It has its significant presence in Ahmedabad, Mumbai and Delhi. But it is not that popular in Bangalore. It was started 30 years ago by a group of 7 members 80 
from the Indian aviation industry who put together ideas of international tours and customized tours with a high level of quality service.

It has B2B network and also boasts of some major tie-ups with General Electronics, TATA, Accenture and some of the noteworthy hotel tie-ups are the Park Inn, Grand Hyatt, Le Meridian to name a few.

CRM Mechanism of Club 7 Holidays: Club 7 Holidays conduct personal visits, tele-calls and communicate with customers through e-mails. They pay special attention to senior citizens and make tailor made packages to suit their convenience. The majority of the clientele database of the organization is due word of mouth publicity. Feedback is taken from customers as a part of its after sales CRM initiative. Old customers who are satisfied with the products and services of the Company enable more referrals. Besides this, advertisements are published in various newspapers and are struggling to make their presence in Bangalore by participating in Travel and Trade shows like IITM.

The plus points of this organization is its metropolitan areas, it gives value for money and has package tours unique only to Club 7 Holidays. The negative points is that its presence in Bangalore is not strong. It is not present in locations which provide the reach for customers. Another drawback this Company faces with the customers is because they do not compromise on their prices. The brand building in north, east and western India has been created already. Hence, the company is trying to use the same goodwill of the brand and penetrating in the South India market. Hence, its strategic alliance with the Future Group has given it the brand association that it requires to boost its identity and thereby attract more customers. 


\section{Analysis and Interpretation}

Table 2: Frequency distribution chart of the different age groups

$$
\text { Re-age }
$$

\begin{tabular}{|c|l|c|c|c|}
\hline \multicolumn{2}{|c|}{ C-I } & Frequency & Percent & Cumulative Percent \\
\hline Valid & $20-29$ & 37 & 61.7 & 61.7 \\
\cline { 2 - 5 } & $30-39$ & 13 & 21.7 & 83.3 \\
\cline { 2 - 5 } & $40-49$ & 5 & 8.3 & 91.7 \\
\cline { 2 - 5 } & $>49$ & 5 & 8.3 & 100.0 \\
\cline { 2 - 5 } & Total & 60 & 100.0 & \\
\hline
\end{tabular}

\section{Correlations}

Table 3: Determining the correlation between Brand Perception (Dependent Variable) and CRM (Independent Variable)

\section{Correlations}

\begin{tabular}{|c|c|c|c|}
\hline & & $\begin{array}{c}\text { Brand } \\
\text { Perception }\end{array}$ & $\begin{array}{c}\text { Customer } \\
\text { Relationship } \\
\text { Management }\end{array}$ \\
\hline Brand & Pearson Correlation & 1 & $.649^{* *}$ \\
\hline Perception & Sig. (2-tailed) & & .000 \\
\hline & $\mathrm{N}$ & 60 & 60 \\
\hline Customer & Pearson Correlation & $.649^{* *}$ & 1 \\
\hline Relationship & Sig. (2-tailed) & .000 & \\
\hline Management & $\mathrm{N}$ & 60 & 60 \\
\hline
\end{tabular}

Interpretation: The above table indicates that CRM and Brand Perception are interdependent with each other and thereby rejecting the null hypothesis that there is no relationship between CRM and brand perception. The values .649 show a very significant correlation. 


\section{Regression}

Table 4: Showing regression values to determine the variation of the dependent variable

Model Summary

\begin{tabular}{|c|c|c|c|c|}
\hline Model & $\mathrm{R}$ & $\begin{array}{c}\mathrm{R} \\
\text { Square }\end{array}$ & $\begin{array}{c}\text { Adjusted R } \\
\text { Square }\end{array}$ & $\begin{array}{c}\text { Std. Error of the } \\
\text { Estimate }\end{array}$ \\
\hline 1 & $.649 \mathrm{a}$ & .421 & .411 & 2.45676 \\
\hline
\end{tabular}

a. Predictors: (Constant), Customer Relationship Management

Interpretation: $\mathrm{R}$ square shows the extent of variation in dependent variable (Brand perception) due to independent variable (CRM). It is understood that when Brand perception is the independent variable it can evoke the same level of variation in CRM.

Table 5: Regression values when Brand perception is the independent variable and CRM is the dependent variable

\section{Model Summary}

\begin{tabular}{|c|c|c|c|c|}
\hline Model & $R$ & $\begin{array}{c}\mathrm{R} \\
\text { Square }\end{array}$ & $\begin{array}{l}\text { Adjusted R } \\
\text { Square }\end{array}$ & $\begin{array}{l}\text { Std. Error of the } \\
\text { Estimate }\end{array}$ \\
\hline \begin{tabular}{l|l} 
dimension0 & 1
\end{tabular} & $.649 \mathrm{a}$ & .421 & .411 & 2.09937 \\
\hline
\end{tabular}

Interpretation: $\mathrm{R}$ Square is the Coefficient of determination. It shows the percentage of variation in the Dependent variable (CRM) by Independent variable (Brand perception) which $42.1 \%$ in this case.

\section{Findings and Observations}

Findings and observations of the study are as follows: There is a significant relationship between CRM and Brand Perception (.649). Thus the null hypothesis is rejected and alternative hypothesis is accepted i.e. CRM and brand perception are related to each other. The hypothesis- Brand perception is dependent upon CRM has been proved with the help of regression and regression coefficients. It was found that there is a significant reciprocal relationship 
between CRM and Brand perception. It was found that not only does Brand perception depend on CRM but even CRM is dependent upon Brand Perception. Due to the brand power, customers perceive the service from the reputed tour operators to be automatically good. Overall study shows that Brand Perception is dependent upon CRM i.e. if a firm has to create a brand image in the minds of the customer then it has very good customer relations.

Company wise results show that there is a significant correlation between CRM and brand perception in all the three sample organizations. Customers are clearly aware of what they want and what they are getting. If there is a gap then firms need to fill this only by improving CRM practices. Brand appearance, reliability, added values and semiotics matter a lot to the customers, a very insignificant number of the respondents were indifferent about brand image which thus proves that there are very bright prospects for customer-brand relationship in tourism in Bangalore. It was found that the firms did not have much loyalty programmes to boast about and the awareness level of the customers related to this also was minimal.

\section{Suggestions}

Well established firms like Thomas Cook enjoy better brand perception and therefore strive to maintain good customer relations. New firms like MakeMyTrip and Club 7 Holidays are striving hard to improve customer and brand relationship in order to develop brand building in the minds of their customers. It is very important to create loyalty programs even in the tourism and hospitality industry and also create awareness with its customers. This will enable customer retention. Tour operators must play an active role in CSR initiatives as customers associate with such brands. Tour operators must work towards brand building simultaneously with improving customer relations. Since, CRM and Brand perception have proved to be interdependent neither of them can be neglected. 


\section{Conclusion}

This study will thus help these firms to look into the areas which might have been neglected, and improve upon areas which is under their control. Reflecting upon some of the answers of the respondents for the semi-structured interview shows that people today are brand conscious when it comes to products and services of the tourism and hospitality industry. Thus, proving that customer brand relationship in Bangalore has strong future prospects and any progress or innovation in this regard will prove to be very productive for tourism. Some of the elements that people looked in a brand of the firm were the amount of benefits received, attractiveness of the products and services as against the competitors. When it came to CRM, some of the first things that came to the minds of the customers about the firms were the way they are treated by the staff, whether it provides value for money or whether it is known for its hassle free dealings with customers. Respondents believe that firms known for their brands will undoubtedly fulfill customer satisfaction. People are also motivated to choose firms which are sensitive to the society. Responses indicated that majority of the people would prefer booking tours from operators who are involved with a CSR (Corporate Social Responsibility) initiative. This indeed is an innovative idea used by the tourism industry to gain customer loyalty and attract new clientele

The concept of zones of tolerance clearly explains that customers enter a service process with a consciously or sub-consciously held view of what constitutes an acceptable, less than acceptable and more than acceptable level of service, based upon prior experiences, the organisation's image, or secondary data sources. Well established tour operators like Thomas Cook enjoy a better zone of tolerance from their customers because their expectations are promptly met. Firms who are comparatively new face minimal zone of tolerance from their customers because established agencies already set a benchmark for customer services.

What constitutes each of these levels may be a very specific notion comprising a clear set of "requirements" or it may be an inexplicit and unstated set of beliefs. Even when a customer has not 
purchased or used a particular service before, it is likely that he/she will have some notion as to what might be acceptable or unacceptable. Those expectations which are considered to be acceptable are within the customer's expectation zone of tolerance and may range anywhere on the scale between ideal an $d$ minimum tolerable (The Zone of Tolerance, 1995).

Ultimately, the revenue generation for any firm depends upon the kind of customer relationship management it practices. Executives of the sample organizations of the study unanimously opine that customer brand relationship is the key to profit maximization. Along with it brand perception will follow. Once the brand image is achieved then efforts are channelized to maintain this brand identity by improving upon differentiating strategies

\section{Reference}

All Business. (n.d.) Computer software customer relation. Retrieved from http://allbusiness.sfgate.com/technology/computersoftware-customer-relation/1348-1.html?

De Leslie, C. (2003). Creating Powerful Brands in Consumer, Service and Industrial Markets. New Delhi: Elsevier Publications

Dickson, R. P., Lassar, W. M., Hunter, G. \& Chakravorti, S. (2009). The pursuit of excellence in process thinking and customer relationship management. Journal of Personal Selling and Sales Management, 29(2), 111-124. doi:10.2753/PSS0885-3134290201

Esse, T. (2003). Securing the value of customer value management. Journal of review of pricing management, 2, 166-171.

Farrell-associates.com.au,. (2013). Welcome: Company profile. Retrieved from http://www.farrell-associates.com.au

ITO,. (n.d.) Retrieved from http:/ / www.ito-ag.ch/17.0.html

Kumar, V. et al.(2006). Customer Relationship Management: A Databased Approach. New Delhi : Wiley-India Edition,

Lynette, R. (2005), Making Customer Relationship Management Work: The Measurement and Profitable Management of Customer Relationships, Journal of Marketing, 69, 252-261. doi:10.1509/jmkg.2005.69.4.252

MakeMyTrip,. Company Profile. Retrieved from http://www.makemytrip.com/about-us/company_profile 
Miguel, M. A. (2006), Relationship quality with a travel agency: The influence of the post-purchase perceived value of a tourism package. Tourism and Hospitality Research, 194-211.

Richard, O. (1997) Satisfaction - A Behavioural Perspective on the Consumer. Singapore: Mc Graw-Hill International Editions

Sarkar, A.N. (2005). Strategic Business Management and Banking, New Delhi : Deep \& Deep Publications

Shainesh, G., \& Mohan, R. Status of Customer Relationship Management in India. Decision Craft. Retrieved from http://www.decisioncraft.com/dmdirect/pdf/crmstatus.pdf

Maklan, S. et al, (2008), New trends in innovation and customer relationship management - A challenge for market researchers. International Journal of Market Research, 50 (2).

Thryambakam, P., \& Bethapudi, A. (2013). Customer Relationship Management Challenges in Hospitality and Tourism Faced by Various Stakeholders in Andhra Pradesh. Global Journal Of Management And Business Studies, 3(1), 1261-1268. Retrieved from

http://www.ripublication.com/gjmbs_spl/gjmbsv3n11_06.pdf Traderslibrary.com,. (2014). -. Retrieved from http://www.traderslibrary.com/moreinfo.asp?item=61809\&SI $\mathrm{D}=\& \mathrm{l} \mathrm{c}=$ moreinfo_related

Verma, V. Harsh. (2002) Brand Management. New Delhi : Excel Books,

Walter, E. (2013). 8 Essentials of Creating a Sustainable Advocacy Program. Building Social Bridges. Retrieved from http:// www.ekaterinawalter.com/2013/09/8-essentials-of-creating-asustainable-advocacy-program/

Xincrm.com,. (2014). Customer relationship management - CRM. Retrieved from http:// xincrm.com/ 